\title{
E-Mindmaps Application Development in Materials of Social and Basic Culture Using Android-Based Groupware
}

\author{
$1^{\text {st }}$ Praharisti Kurniasari \\ Study Program on Sport Physical Education and Recreation \\ of IKIP Budi Utomo Malang \\ Malang, Indonesia \\ kurniasaripraharisti@gmail.com
}

\author{
$2^{\text {nd }}$ Agusti Mardikaningsih \\ Study Program on Sport Physical Education and Recreation \\ of IKIP Budi Utomo Malang \\ Malang, Indonesia \\ agustim@gmail.com
}

\begin{abstract}
This study aims to produce basic social and cultural teaching materials using the e-mindmap application utilizing Android-based groupware that is feasible and effective to increase the motivation of the students of Sport Physical Education and Recreation Study Program at IKIP Budi Utomo Malang. Specifically, this study aims to 1) identify the development needs of basic social and cultural materials by using the e-mindmap application utilizing android-based groupware to increase the motivation of the students, 2) compiling basic social and cultural teaching materials by using the e-mindmaps application utilizing android-based groupware to increase the motivation of students, 3) disseminating product design (e-mindmap application design) in the study programs. This type of research is development research (Research and Development/RD). The media development model is based on six stages, namely the concept, planning, material collecting, testing, assembly and distribution. This research resulted in yielding some data,those are the data of material validation results that is $81.1 \%$, a decent category with a good predicate; and the result of media validation that is $80.83 \%$, a decent category with a good predicate.
\end{abstract}

Keywords: teaching materials, basic social culture, emindmaps, android applications

\section{INTRODUCTION}

The development of National Education is a conscious or planned effort to realize the learning atmosphere and learning process so that students actively develop their potential to have spiritual power, religion, self-control, habits, intelligence, and skills needed for themselves, society, nation and country (Article 1 of Law No. 20 of 2003).

The development of information technology also affects the competencies needed in the world of education. Students must have the competencies needed by the world. The increasing of innovation in learning in higher education must continue to be done so that the quality of graduates has better competencies. The whole process, both in the form of teaching methods and learning experiences, has an effect on the learning process. Lecturers as a source of learning informationstell the messages into lternspecific symbols (encoding) and students as recipients of the ltern-symbol interpretation so that they are understood as messages (decoding) [1]. The important point is about the the delivery process of material by lecturers to students that can be captured by students through well understanding.

Learning media is a very strategic tool for educators to transfer knowledge to students. Learning media can stimulate students to use more of their senses than the case in which the lecturer only gave verbal information as it was usually done. Audio-visual learning media is also able to arouse students' emotions so the student interest in learning a material is increased. Mind Map is a method of recording where the record is the easiest method for placing information into the brain and removing information from the brain. Including a mind map on a learning media is one of the efforts to improve students' memory about a delivered material, [2].

At the IKIP Budi Utomo Malang the use of media in learning has been done. Efforts made by universities can be observed from the facilities; LCD projector, theoretical and practical classes. The media used commonly is power point presentations whose use has not led to interaction with students so that students are less interested in the material presented. Learning media accompanied by mind maps in basic social and cultural science (ISBD) courses have not been developed. In some mind map studies there is also no one that combines mind maps with learning media, for example the research conducted by Ghea Putri Fatma Dewi, Development of Educational Games for the Introduction of Animal Names in English as Elementary Student Learning Media Based on Macromedia Flash, has not been accompanied by a mind map. Research conducted by Yumi Hartati, Application of Mind Mapping Methods as an Effort to Improve Creativity and Understanding of Students in Learning Social Studies Class VIII C SMP N 4 Wonosari, has not incorporated mind maps in learning media. Though the use of 
Data collection using instruments included: interview guides for students, print and application validation sheets by material experts, printed validation sheets and application by media experts, printed validation sheets and applications by linguists, student response questionnaires to applications, learning implementation sheets, sheets field notes, and concept comprehension tests.

\section{RESULTS AND DISCUSSION}

This research produced a product in the form of a concept map in the form of electronic media that can be accessed via each student's smartphone on-line. This aplication can be downloaded at playstore for free. This research product was made using the E-mindmaps application, with the aim of getting a concept map that is not only a concept map but also contains material, animation, and interactive multimedia in the concept map The application component consists of an introductory, content, and closing section. The interface section consists of cover, front page, preface, application usage instructions. The type, color, and size of the letters used are arranged proportionally to make it interesting to be read by the user. The front page's color is yellowish orange and it has the application title and start button. Front page contains the title of the application, author, and institution with an orange background. The preface page contains a brief guide to the application. The example of the front page of the application is presented in Fig1.

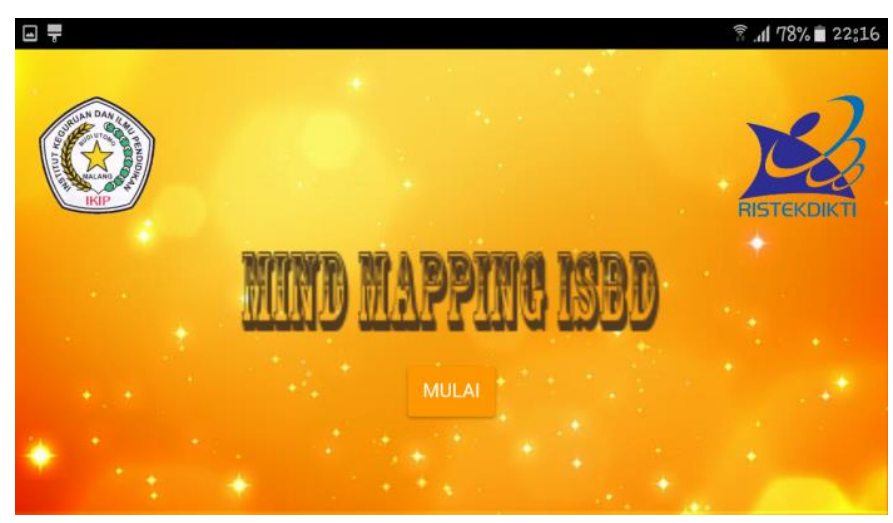

Fig 1. The front page of the application
The location of this research was in the IKIP Budi Utomo Malang. The selection of research areas was based more on efforts to fulfill and comprehend the data related to the focus of the research problem. In accordance with the type of data needed in this study, the data collection in this study adhered to the principle of "the researcher is the main research instrument", but in its implementation, the researcher also implemented several aid data collection tools. Based on the approach and characteristics of the research, then the data analysis in this study were carried out continuously from the beginning to the end of the entire research process. 


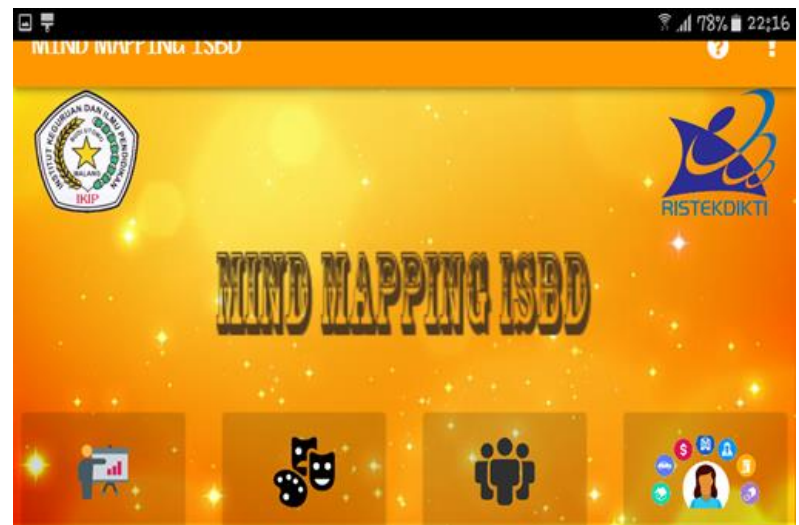

Fig 2 Menu display page

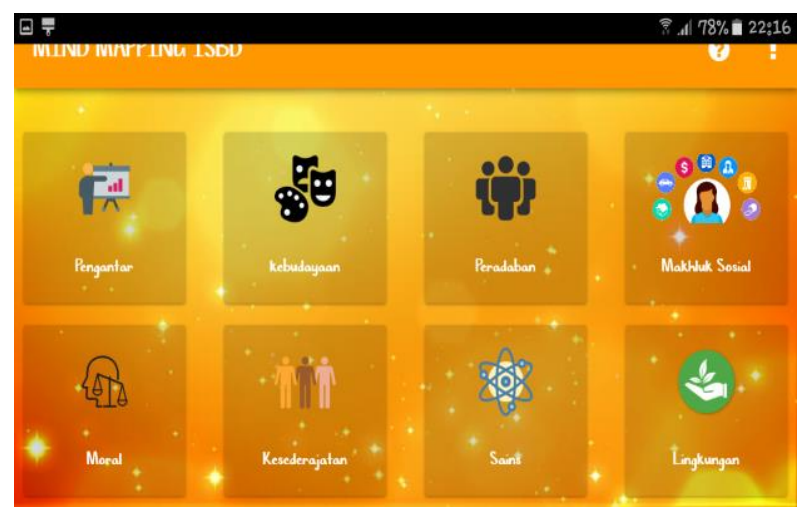

Fig 3. Menu display page

The application usage instructions page is equipped with buttons to make it easier for users to access the parts of the application. Examples of application usage instructions pages are shown in Fig 4.

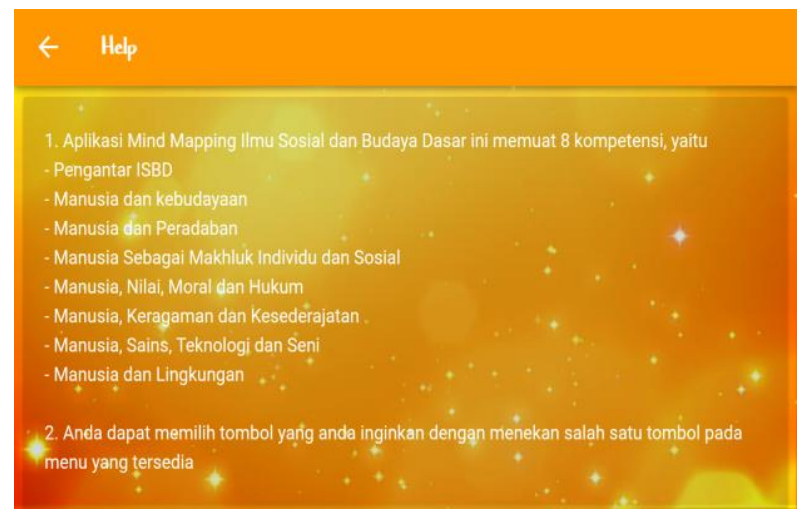

Fig 4. Application usage instructions page
The contents section consists of 8 chapters, and the material will be explained into mind maps. Each of the chapters and subchapters can be hyperlinked. Examples of material descriptions presented in Fig 5.

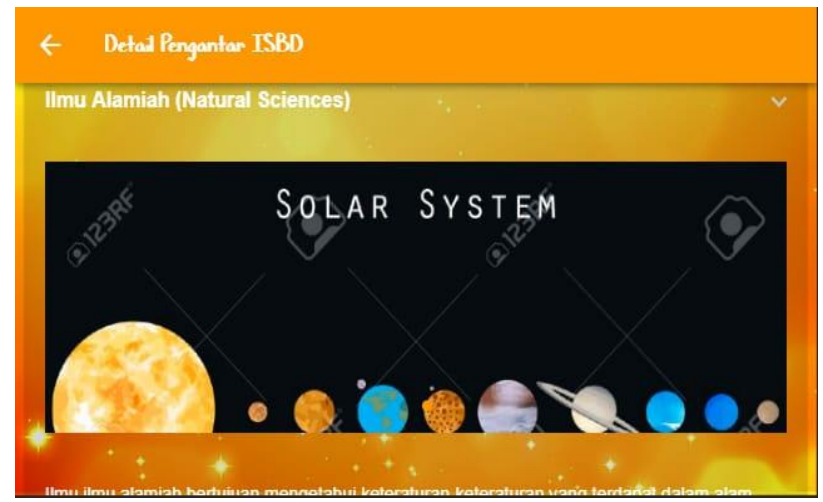

Fig 5. Description of the material and links related reference sources.

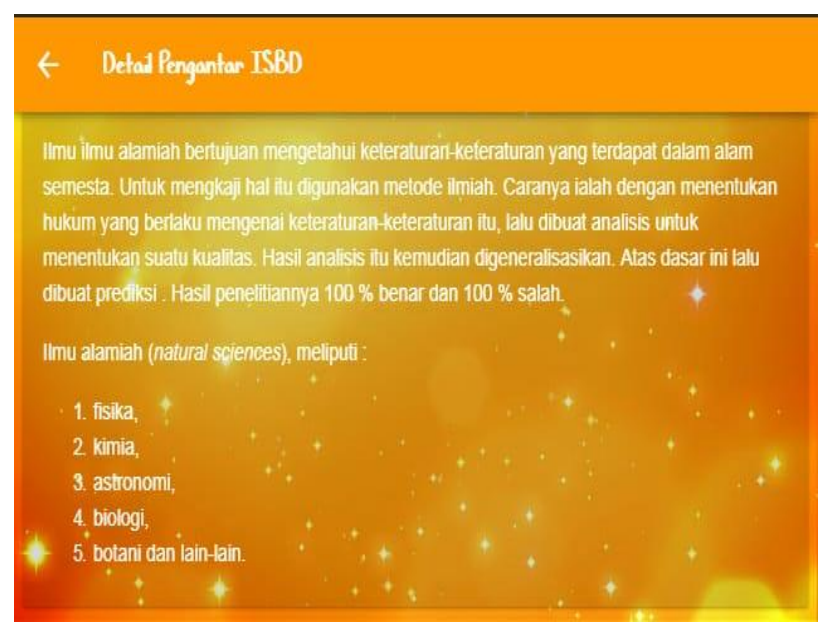

Fig 6 Description of the material

The chapter in the content section consists of basic socialcultural science materials in the form of mind maps. In the description of the material, it is also equipped with links to access internet resources that are as supporting material. Examples of material descriptions presented in Figure 6.

Validation of application teaching materials by media experts consists of application validation. The results of application validation by media experts are presented in Table 1 . 
Based on the calculation of the results of the validation of Android-based applications by material experts,the material relevance component and material organization have a decent category with a good predicate, while the effect component for learning strategies has a decent category with very good predicate. The calculation of the overall product feasibility percentage shows that the Android-based application has a decent category with a good predicate $(81.1 \%)$ so that no overall revision is needed.

Validity test is conducted on lecturers as experts. Sugiono [3] states the validity of non-test instruments is sufficient to meet construct validity. Testing the validity of construction can be used the opinions of expert (judgment expert). According to Messick as quoted by Mc Clure the value obtained by the media that has been validated by experts can be a reference to determine whether the media can be used by researchers to be continued for further testing or not

Georgiev, et al explained that despite all its shortcomings, mobile learning will become more popular with the advancement of information and communication technology. Mobile learning in general use in traditional education will be in accordance with educational needs to improve its quality.

\section{CONCLUSION}

Development of basic social sciences teaching materials using an Android-based e-mind maps application is feasible, interesting and in accordance with the criteria to be applied in learning in the PJKR IKIP study program Budi Utomo Malang.

Validation results for Android-based teaching materials according to media experts and linguists are in the decent category with good predicate $(80.83 \%$ for media aspects and $81.1 \%$ for material aspects).

The revisions were focused on the consistency of the type of letters, the quality of the illustration images and their information, as well as the unclear images.

\section{REFERENCES}

[1] Azhar Arsyad. 2013. Media Pembelajaran. Jakarta: Raja Grafindo Persada.

[2] Buzan, Tony. 1986. Use Your Memory. Great Britain: The British Broadcasting Corp.

[3] Sugiyono. 2010. Metode Penelitian Pendidikan, Pendekatan Kuantitatif, Kualitatif, dan R\&D. Bandung: Alfabeta. Depdiknas 